\title{
KEDUDUDKAN EKONOMI CHETTIAR DI TANAH MELAYU, 1945-1957
}

\author{
Ummadevi Suppiah \\ Sivachandralingam Sundara Raja
}

\begin{abstract}
This article examines the role played by the Chettiars in the economic developn:ent of Malay before the Second World War which has been largely ignored by local his ians in the study of Malayan economic history, especially from 1945 until 1957. The Ch. tiar conmunity played an important role in the economic development of Malaya from the beginning of the twentieth century until the Second World War. The dominunt role of the Chettiars in the Malayan economy became either irrelevant or disappeared altogether during the Japanese occupation due to the use of Japanese currency in transactions. When the British returned to Malaya after the Japanese occupation, they did not recognize the Japanese currency and declared it worthless. The latter paid very little compensation under the War Damage Contpensation Scheme against losses suffered by the Chettiars. This complicated the economic position of the Chettiars and many Chettiars ended their money lending activities; sold off their mbber plattations and tin mines to Chinese businessmen and returned to India. Within this context, it is pertinent to study how the Japanese occupation affected the economic position of the Chettiar community and why the British did not favour the Chettiars through contpensation schemes and legislation even thongh the Chettiars had contributed enornously to the development of the Malayan economy before Second World War.
\end{abstract}

\section{Pendahuluan}

Chettiar telah memainkan peranan penting dalam pembangunan ekonomi Tanah Melayu mulai awal abad ke-20 sehingga tercetusnya 
Perang Dunia Kedua. Melalui kegiatan peminjaman wang, mereka telah melibatkan diri dalam industri perlombongan dan getah dan ramai yang menjadi pemilik ladang getah dan lombong. Mereka juga membuka bank untuk terlibat dalam perdagangan dengan koloni-koloni British di AsiaTenggara dan Asia Selatan. Peranan dominan Chettiar dalam ekonomi Tanah Melayu sebelum Perang Dunia kedua lenyap pada era pendudukan Jepun akibat penggunaan mata wang Jepun dalam urusniaga dan transaksi wang di Tanah Melayu dan negara jajahan Jepun di seluruh Asia Tenggara.

British yang kembali ke Tanah Melayu selepas pendudukan Jepun telah merumitkan kedudukan ekonomi komuniti Chettiar dengan tidak mengiktiraf mata wang Jepun dan membayar pampasan dalam dollar-sterling (bawah Skim Pampasan Kemusnahan Perang) terhadap kerugian yang dialami oleh Chettiar. Nilai pampasan yang diterima oleh Chettiar amat kecil dan mereka tidak terdaya untuk meneruskan kegiatan ekonomi mereka. Ramai dalam kalangan Chettiar mula menjual ladang getah dan lombong kepada pengusaha Cina dan kembali ke India. Secara umum pendudukan Jepun telah menjejaskan kedudukan ekonomi Chettiar (dengan pengenalan mata wang Jepun) dan British yang kembali ke Tanah Melayu selepas perang tidak membela Chettiar di bawah Skim Pampasan Kemusnahan Perang dan perundangan walaupun Chettiar telah memainkan peranan penting dalam pembangunan ekonomi Tanah Melayu sebelum Perang Dunia Kedua.

\section{Kegiatan Ekonomi Chettiar Pada Era British, 1800-1942}

Nama ceti ${ }^{1}$ atau Chettiar ${ }^{2}$ adalah sinonim dengan aktiviti peminjaman wang di Tanah Melayu. Namun ramai tidak mengetahui bahawa komuniti Chettiar turut melibatkan diri dalam perdagangan candu, insuran dan bidang ekonomi komersial seperti perladangan getah serta perlombongan di Tanah Melayu. Kedatangan komuniti Chettiar ke Tanah Melayu tidak dapat diberi satu pentarikhan yang khusus tetapi rekod British mempunyai catatan tentang kehadiran dan kegiatan mereka pada abad ke-19 dan ke-20. ${ }^{3}$

Abad ke-19 menyaksikan perluasan kegiatan British di Asia Tenggara dengan penguasaan Singapura pada 1819 dan seterusnya perluasaan kegiatan perdagangan melalui perjanjian-perjanjian perdagangan seperti Burney (1826) di Negeri-negeri Melayu, Bowring (1855) di Thailand dan Perjanjian Yandaboo (1826) di Burma.

Perluasaan perdagangan membuka ruang bagi pengaliran modal asing di rantau Asia Tenggara. Peluang ekonomi yang sedia wujud di koloni-koloni British di luar India menjadi faktor tarikan bagi komuniti 
Chettiar untuk berhijrah ke Tanah Melayu. Mulai pertengahan abad ke19 hingga abad ke-20, dasar laissez-faireBritish telah memberi peluang kepada komuniti Chettiar untuk melibatkan diri dalam industri perladangan getah dan perlombongan bijih timah di Tanah Melayu. ${ }^{4}$ Antara 1870 hingga 1880-an, komuniti Chettiar membiayai sepenuhnya perdagangan candu di Singapura dan Pulau Pinang. ${ }^{5}$ Pada akhir abad ke-19 sehingga pertengahan awal abad ke-20, komuniti Chettiar merupakan pembekal utama kredit kepada pengusaha Cina yang membuka hutan di Tanah Melayu bagi mengusahakan tanaman getah dan melombong bijih timah. Tan Chay Yan (penanam pokok getah pertama di Melaka) ${ }^{6}$ dan Tan Cheng Lock (pengasas MCA) mendapat pinjaman wang daripada komuniti Chettiar untuk membangunkan industri getah di Melaka. ${ }^{?}$

Pada masa yang sama, komuniti Chettiar juga turut melibatkan diri dalam industri getah. ${ }^{8}$ Di Melaka sahaja komuniti Chettiar telah memiliki 50,000 ekar tanah ladang getah. ${ }^{9}$ Komuniti Chettiar turut meminjamkan wang kepada komuniti Melayu yang terdiri daripada petani (penanam padi), pekebun kecil getah, penjawat awam dan golongan aristokrat. Mereka juga menjadi pemajak kawasan perlombongan, khususnya di negeri Perak dan Selangor. ${ }^{10}$ Di samping itu, Chettiar juga telah menubuhkan beberapa buah bank dalam usaha memodenkan urusan peminjaman wang, memudahkan transaksi dan pengiriman wang serta melibatkan diri dalam pasaran saham. ${ }^{11}$

Kedudukan ekonomi komuniti Chettiar bertambah kukuh di sekitar tahun 1930-an apabila berlaku k emelesatan ekonomi yang telah menjejaskan perdagangan getah dan pendapatan pekebun kecil Melayu. Keadaan ini telah memaksa orang Melay u menjual tanah-tanah ladang yang dicagar kepada Chettiar. Demi untuk melindungi orang Melayu, British telah menggubal beberapa undang-undang untuk mengawal aktiviti ekonomi Chettiar mulai 1920 - 1930-an. Usaha British ini tidak berjaya tetapi sebaliknya kedudukan ekonomi Chettiar tetap kukuh sehingga Perang Dunia Kedua.

\section{Kegiatan Ekonomi Chettiar Semasa Pendudukan Jepun, 1942- 1945}

Zaman pendudukan Jepun telah memperlihatkan kepelbagaian status sosioekonomi setiap bangsa kerana setiap lapisan masyarakat telah mengalami keperitan hidup akibat pelbagai kekurangan yang serius dalam sistem pentadbiran tentera Jepun di Tanah Melayu. ${ }^{12}$ Mulai tahun 1942, Jepun mula melaksanakan polisi ekonomi terkawal bagi penduduk di Tanah Melayu. ${ }^{13}$ Walaupun, sistem pentadbiran British 
dikekalkan pada beberapa bulan awal pendudukan Jepun tetapi lamakelamaan pengaruh Jepun dapat dilihat dalam setiap aspek pentadbiran dan pemerintahan mereka di Tanah Melayu. Pada 23 Februari 1942, tentera Jepun mengisytiharkan mata wang Jepun, 'yen' sebagai wang rasmi (legal tender) di Tanah Melayu dan dianggap sama nilai dengan 'straits dollar'. It

Tentera Jepun mula mengawal penggunaan mata wang 'straits dollar' dan ini mendorong penduduk Tanah Melayu menyembunyikan mata wang tersebut dan mula menggunakan mata wang Jepun atas paksaan tentera Jepun. Kerajaan Jepun mula mencetak mata wang Jepun dalam kuantiti yang banyak tanpa menghiraukan nilai muka. Keadaan ini menyebabkan nilai mata wang Jepun merudum pada tahun 1944 dan 1945. Keadaan ini juga telah membawa kepada kemunculan pasaran mata wang gelap serta penawaran mata wang Jepun melebihi permintaan penduduk di Tanah Melayu. Akibatnya berlaku inflasi dan kuasa membeli penduduk menurun.

Semasa pendudukan Jepun, warga komuniti Chettiar yang beroperasi di Tanah Melayu ialah ejen-ejenChettiar yang tidak berpeluang untuk pulang ke India semasa perang. ${ }^{15}$ Lazimnya, Principal $^{16}$ akan tinggal di Madras dan memberi arahan tugas dari masa ke semasa kepada ejen-ejen mereka di Tanah Melayu. Semasa pendudukan Jepun, segala bentuk komunikasi terputus antara Tanah Melayu dan India. Dalam suasana ini, Principal di India tidak dapat mengeluarkan sebarang arahan ataupun memberi sebarang kuasa kepada ejen untuk mengendalikan urusan peminjaman wang selain daripada wang 'straits dollar' di Tanah Melayu. Dalam suasana ini, terdapat dalam kalangan ejen telah bertindak atas kapasiti sendiri untuk melakukan transaksi kewangan. Para ejen juga telah menerima ugutan untuk membayar levi sebanyak $17^{1 / 2}$ peratus daripada perolehannya kepada Indian National Army (INA). ${ }^{17}$ Dalam hal ini, Chettiar (Principal) menjadi mangsa keadaan yang tersepit antara tindakan ejen-ejennya semasa pendudukan Jepun disebabkan polisi tentera Jepun.

Pentadbiran Jepun telah menggalakkan ejen-ejen Chettiar untuk meneruskan kegiatan peminjaman wang secara perseorangan dan didapati lama-kelamaan kebanyakan firma-firma besar peminjaman wang komuniti Chettiar tidak beroperasi sepenuhnya. Hal ini disebabkan tentera Jepun yang menguatkuasakan ordinan Tomi Seirei No.19 (Toku Beta-si, Notice no. 160$)^{18}$ bagi mengawal kegiatan peminjaman wang Chettiar. Dalam waktu yang sama, kerajaan Jepun telah menubuhkan The Peoples' Bank atau Peoples Treasury (Shomin Ginko) untuk menghalang aktiviti peminjam wang dan pemegang pajak 
gadai (pawnbroker) daripada membekalkan modal kepada peniaga kecil di Tanah Melayu.

Pihak tentera Jepun juga telah mengugut ejen-ejen Chettiar untuk menjalankan aktiviti transaksi dalam mata wang Jepun. Dilaporkan komuniti Chettiar yang enggan menerima arahan tentera Jepun telah didera atau ditahan dalam penjara. ${ }^{19}$ Tentera Jepun telah menyerbu beberapa rumah komuniti Chettiar di bandar Melaka dan telah merampas mata wang'straits dollars' dalam simpanan mereka. ${ }^{20}$ Dalam keadaan ini, Chettiar mula menerima bayaran hutang dalam mata wang Jepun dan para penghutang pula telah mengambil kesempatan ini untuk menuntut dokumen pinjaman wang termasuk geran tanah yang telah dicagarkan setelah melangsaikan hutang mereka.

Pada era pendudukan Jepun, mereka telah membenarkan pengoperasian bank-bank Chettiar di Tanah Melayu seperti The Indian Bank dan Indian Overseas Bank ${ }^{21}$ bagi menghalang aktiviti bank-bank British. Pada masa yang sama, pentadbir Jepun tidak menggalakkan pembukaan cawangan-cawangan bank Chettiar yang baharu. Ini terbukti apabila pada 11 Jun 1942, permohonan Shanmugam Chettiar untuk membuka cawangan Chettinad Bank di Kuala Lumpur ditolak oleh kerajaan Jepun. ${ }^{22}$ Pengusaha bank dalam kalangan komuniti Chettiar khuatir sekiranya mereka tidak meneruskan aktiviti perbankan, wang deposit mereka akan dibekukan atau tidak dapat dipindahkan ke India. Pada 5 September 1945, baki deposit The Indian Overseas Bank dan Indian Bank Ltd. di Pulau Pinang, masing-masing ialah \$6,630,216.06 dan \$ $7,766,178.11$ (mata wang Jepun)..$^{23}$

Walaupun komuniti Chettiar dibayar pampasan oleh tentera Jepun bagi pengambilan ladang getah, tetapi mereka tetap mengalami kerugian yang besar disebabkan pemusnahan ladang-ladang getah milik mereka akibat pengeboman sewaktu pendudukan Jepun. ${ }^{24}$ Komuniti Chettiar merasa amat tertekan dengan kerugian berterusan yang dialami semasa pendudukan Jepun.

\section{'Moratorium ' Dan Kemelut Mata Wang}

Pada 15 Ogos 1945, sejurus selepas Jepun menyerah kalah, British mengumumkan 'Proclamation' sebagai langkah awal untuk menjajah semula Tanah Melayu. Mulai September 1945 sehingga April 1946, British telah memperkenalkan Pentadbiran Tentera British (PTB) atau (British Military Administration) di Tanah Melayu dan Singapura. PTB mengumumkan 'Moratorium Proclamation' ${ }^{25}$ untuk menutup semua institusi kewangan dan menghalang urusan tanah dalam tempoh masa pelaksanaan Proclamation. ${ }^{26}$ PTB juga mengisytiharkan 'Currency 
Proclamation' yang menetapkan mata wang Negeri-negeri Selat dan Tanah Melayu (Malayan Notes) sebagai matawang rasmi di Tanah Melayu dan mata wang selain daripada itu diharamkan. ${ }^{27}$ Dengan itu, mata wang Jepun diumumkan sebagai tidak sah dan bernilai. Hal ini kerana mengikut undang-undang antarabangsa, apabila sesebuah negara dijajah semula oleh kuasa lain maka negara itu dianggap sebagai wilayah musuh dan kuasa pendudukan serta penduduk negara itu juga akan dianggap musuh.

Menurut Tej Bahadur, undang-undang antarabangsa melarang kuasa pendudukan mengubah corak pentadbiran dan pemerintahan sebelumnya. ${ }^{28}$ Dengan itu, penguatkuasaan mata wang Jepun sebagai mata wang rasmi oleh tentera Jepun semasa pendudukan mereka adalah salah di sisi undang-undang antarabangsa. Dengan itu, segala urus niaga dan harta yang terkumpul semasa pend udukan juga dianggap sebagai harta musuh. Sehubungan dengan itu, komuniti Chettiar di Tanah Melayu mula merasa cemas dengan kedudukan ekonomi mereka akibat 'Currency Proclamation'. Mereka telah menanggung kerugian yang amat besar ekoran pengisytiharan ini. Selepas tamatnya pendudukan Jepun, kerugian komuniti Chettiar di Tanah Melayu dianggarkan sebanyak 120 juta 'straits dollar'. Sebahagian daripadanya adalah kerugian pelaburan dalam industri perladangan getah dan separuh lagi dalam aktiviti peminjaman wang. Mereka yang menjalankan perniagaan di Tanah Melayu turut menanggung beban hutang akibat pinjaman modal daripada firma-firma induk milik komuniti Chettiar dan institusi kewangan di India Selatan.

Dalam menghadapi krisis atau kemelut mata wang dan untuk membela nasib mereka, komuniti Chettiar telah bersatu di bawah $A l l$ Malaya Nattukottai Chettiars Chamber of Commerce yang ditubuhkan pada tahun $1946^{29}$ untuk menghantar petisyen kepada Setiausaha koloni di London terhadap kedudukan ekonomi komuniti mereka di Tanah Melayu. Mereka juga telah mengundang Subbiah Chettiar, Pengarah Pengurusan The Indian Overseas Bank, Madras dan Ramanathan Chettiar, seorang peguam untuk menjadi jurucakap bagi pihak mereka. Mereka turut mendapat khidmat nasihat daripada pakar perundangan koloni di Tanah Melayu, iaitu Sir Roland Braddell ${ }^{30}$ dan Khoo Teik Ee (peguam terkenal di Kuala Lumpur) serta beberapa peguam "31 yang arif dalam perundangan antarabangsa untuk memberi pandangan dan menyediakan memorandum kepada kerajaan koloni.

Pada 5 Februari 1947 dan 18 Mac 1947, Ramanathan Chettiar, Setiausaha All Malaya Nattukottai Chettiars Association telah menulis surat kepada Setiausaha Koloni di London untuk mendesak pihak kerajaan koloni agar menggubal satu undang-undang dengan serta-merta bagi 
melindungi hak dan kedudukan ekonomi komuniti Chettiar di Tanah Melayu sebelum Moratorium ditarik balik. ${ }^{32}$ Komuniti Chettiar juga mencadangkan supaya dibuka semula segala urusan transaksi semasa pendudukan Jepun dan menetapkan beberapa prinsip apabila keskes itu dibawa ke mahkamah. Dalam hal ini, komuniti Chettiar lebih berminat untuk mendapat pampasan ke atas hutang-hutang sebelum pendudukan Jepun yang dijangka telah selesai atau separuh selesai yang dibayar oleh penghutang semasa pendudukan Jepun.

Memandangkan desakan yang berterusan daripada komuniti Chettiar, maka, pada 31 Julai 1946, pejabat koloni di London telah menemu ramah W.D. Woellwarth (peguam komuniti Chettiar di Tanah Melayu) dan En A. Subbiah. Kedua peguam ini telah menyampaikan hasrat komuniti Chettiar seperti yang berikut:

\begin{abstract}
...Government should not further penalize the Chettiars by taking away any of the other legal rights and remedies which already exist and to which they can individually resort for the recovery of their lost assets....as in the present instance, such legislation is likely to result in grave injustice to a large community which has contributed considerably to the welfare of Malaya in the past, an injustice which in itself would be directly attributable to governments' action in repudiating their obligations under International law. ${ }^{33}$
\end{abstract}

Komuniti Chettiar juga berjanji untuk meneruskan kegiatan ekonomi mereka dan bekerjasama dengan pentadbiran British untuk membangunkan semula Tanah Melayu serta memulihkan kehidupan penduduk Tanah Melayu seperti sediakala. Walaupun demikian, pihak PTB telah bertindak mengikut peruntukan undang-undang antarabangsa serta perundangan yang bakal digubal khusus oleh kerajaan koloni untuk memutuskan perkara pampasan kepada penduduk Tanah Melayu. Pada masa yang sama, kerajaan koloni juga menghadapi masalah besar untuk menetapkan satu nilai kepada semua transaksi yang berlaku dalam mata wang Jepun.

Kebanyakan peguam yang menasihati komuniti Chettiar berhubung kedudukan ekonomi mereka di Tanah Melayu, berpendapat komuniti Chettiar tidak boleh bertindak di luar perundangan antarabangsa dan koloni di Tanah Melayu. Oleh itu, komuniti Chettiar telah mempersoalkan status mereka yang selama ini dianggap sebagai 'warganegara British-India' (British-India subject). Ini bererti jika pihak koloni menerima mereka sebagai penduduk 'British-India', maka segala harta yang dikumpulkan oleh komuniti Chettiar sebelum dan semasa perang boleh dianggap sebagai sah. Principal juga sanggup memutuskan hubungan dengan ejen-ejennya di Tanah Melayu atas dasar ini. Walau 
bagaimanapun, usaha itu menghampakan komuniti Chettiar kerana pihak British di Tanah Melayu bertekad untuk mengawal keadaan dengan penguatkuasaan undang-undang. Oleh itu, komuniti Chettiar tiada pilihan lain selain menantikan penggubalan satu undang-undang bagi memutuskan status transaksi yang berlaku dalam mata wang Jepun. ${ }^{34}$ Mereka juga meminta pihak koloni untuk mengadili situasi itu dari perspektif kerajaan atau pentadbiran British sebelum pendudukan Jepun di Tanah Melayu.

Dalam suasana ini, British membatalkan Moratorium sebaik sahaja mengasaskan kerajaan Malayan Union pada bulan April 1946. Kerajaan Malayan Union di bawah arahan sekretariat kerajaan koloni di London mula merancang langkah-langkah segera untuk mengatasi masalah kemelut mata wang supaya dapat menjaga kepentingan dan kebajikan semua lapisan masyarakat di Tanah Melayu. ${ }^{35}$ Sebagai langkah terawal, British mengusahakan penubuhan Lembaga Tabung Kemusnahan di Tanah Melayu.

\section{Skim Pampasan Kemusnahan Perang}

Sebelum digubal satu kerangka perundangan bagi mengawal situasi yang sedang meruncing akibat kemelut matawang, pada 1 Januari 1947, PTB telah menubuhkan Lembaga Kemusnahan Perang (War Damage Commission) ${ }^{30}$ untuk menilai segala tuntutan kemusnahan perang yang diterima daripada penduduk Tanah Melayu. Lembaga ini juga berfungsi untuk menyediakan laporan serta mengemukakan cadangan kepada kerajaan Malayan Union untuk memutuskan sama ada pampasan yang dituntut diluluskan ataupun tidak. Segala tuntutan mesti ke atas harta yang musnah dalam tempoh masa 8 Disember 1941 hingga 31 Mac 1946. Lembaga ini juga berperanan untuk menerima tuntutan-tuntutan harta yang diambil oleh kerajaan sebelum negara ini diduduki oleh Jepun dan akan menghantar segala tuntutan ini kepada pegawai Tuntutan Bersama

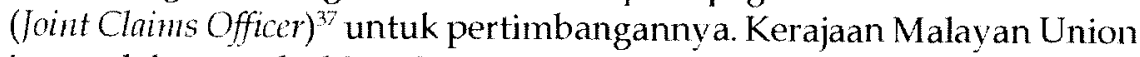
juga telah menubuhkan Jawatankuasa 'Japanese Raparations' untuk meninjau tuntutan kerajaan British terhadap kerajaan Jepun sebagai menampung sebahagian daripada perbelanjaan bayaran pampasan kepada penduduk Tanah Melayu ${ }^{38}$ Kerajaan koloni di London telah mengasaskan Skim Kemusnahan Perang pada tahun 1949 di bawah War Damage Fund, Ordinance 1949 untuk melancarkan proses bayaran pampasan serta membangunkan semula ekonomi Tanah Melayu. ${ }^{39}$

Sehubungan dengan itu, komuniti Chettiar telah mengambil kesempatan ini untuk membuat tuntutan ke atas kemusnahan harta mereka pada waktu perang termasuklah pokok getah, bilangan cawan susu getah, pagar di sekeliling tanah ladang, rumah buruh estet 
('lines'), rumah kediaman Chettiar serta perabot dan perkakas rumah. ${ }^{40}$ Misalnya, Ramanathan Chettiar telah menuntut ganti rugi sebanyak \$ 13,500 ke atas 2700 batang pokok getah yang dimusnahkan oleh tentera Jepun untuk menanam ubi kayu. Walau bagaimanapun, pampasan yang diluluskan adalah sebanyak $\$ 2530 .^{41}$

Nasib yang sama turut dirasai oleh komuniti Chettiar di negerinegeri lain di Tanah Melayu. Adakalanya wang pampasan dikurangkan ataupun tuntutan ditolak selepas siasatan mendapati maklumat kemusnahan adalah kurang tepat. Contohnya, Ramasamy Chettiar hanya dibayar $\$ 280$ daripada jumlah yang dituntut, iaitu $\$ 1082$ kerana mengatakan tanahnya ditanam dengan getah sedangkan laporan penyiasatan membuktikan tanah ladangnya ialah tanah kosong. ${ }^{42}$ Tuntutan Kathiresen Chettiar pula ditolak kerana mengemukakan tuntutan sebanyak $\$ 8100$ kepada Lembaga sedangkan pada tahun 1945 , Chettiar telah pun menerima pampasan sebanyak $\$ 2800$ daripada tentera Jepun untuk pokok-pokok getah yang musnah. ${ }^{43}$ Komuniti Chettiar juga gagal mendapat pampasan penuh akibat tidak dapat mengemukakan dokumen-dokumen rasmi yang didapati musnah, hilang atau rosak akibat pendudukan Jepun. Meyappa Chettiar antara lain telah diminta untuk mengemukakan geran-geran tanah supaya dapat menuntut kemusnahan ke atas ladang-ladang getah sebanyak 274 ekar di Sitiawan, Perak. ${ }^{44}$

Peranan ejen Chettiar didapati berterusan selepas pendudukan Jepun kerana principal yang berada di Presidensi Madras, India Selatan terikat dengan peraturan imigresen y ang agak ketat di India dan Tanah Melayu sehingga mengganggu lawatan mereka ke Tanah Melayu. Kebanyakan tuntutan komuniti Chettiar dikemukakan melalui ejenejen Chettiar di Tanah Melayu. Adakalanya ejen-ejen ini tidak dapat menuntut pampasan kerana principalnya di India sudahpun meninggal dunia semasa pendudukan Jepun dan warisnya tidak boleh memasuki Tanah Melayu akibat peraturan imigresen yang ketat di bawah kerajaan Malayan Union. Tambahan pula, ejen-ejen diminta mengemukakan surat pelantikan 'Power of Attorney'. Dalam kes PL. Palaniappa Chettiar yang bertindak sebagai ejen kepada M.R.PL. Palaniappa Chettiar, PL. Palaniappa Chettiar bukan sahaja tidak diberikan sebarang pampasan, malahan wang ganti rugi sebanyak $\$ 822$ telah diserahkan kepada 'Collector of Estate Duty' kerana ejennya dikatakan '... no legal standing in respect of the above deceased's estate'. ${ }^{55}$ Ada juga dalam kalangan komuniti Chettiar diisytiharkan muflis akibat tindakan ejen yang telah menjual segala harta principal semasa pendudukan Jepun.

Terdapat juga dalam kalangan komuniti Chettiar yang telah menuntut semula hutang yang dibayar dalam mata wang Jepun dan 
mengenakan potongan gaji dan pencen ke atas penghutang setelah dipersetujui oleh pejabat kerajaan. Dalam kes Tunku Kalsom binti Sultan Abdul Hamid (Alor Setar, Kedah), Alagappa Chettiar menuntut semula hutang yang sudahpun dibayar selesai oleh Tunku Kalsom dalam matawang Jepun. ${ }^{46}$ Pada 11 Januari 1950, Tunku menulis kepada Setiausaha Kerajaan Kedah untuk memaklumkan bahawa komuniti Chettiar mengira semula hutangnya dalam matawang rasmi Tanah Melayu dan memintanya untuk membayar $\$ 93.75$ setiap bulan atas arahan State Council. Tunku yang enggan membayar semula hutangnya telah mencadangkan agar Chettiar membawa kes ini ke muka pengadilan.

Walaupun komuniti Chettiar menghadapi banyak halangan dan kesulitan untuk menuntut balik kerugian yang dialami tetapi pihak Lembaga Kemusnahan Perang dan kerajaan koloni di Tanah Melayu turut menghadapi masalah apabila jumlah tuntutan wang penduduk melebihi jumlah tabung Skim Kemusnahan Perang. ${ }^{47}$ Komuniti Chettiar tidak dapat menuntut ganti rugi sepenuhnya daripada Skim Kemusnahan Perang kerana syarat-syarat tuntutan skim yang amat ketat. British di Tanah Melayu juga tidak dapat memberi ganti rugi kepada segala deposit yang terkumpul dalam mata wang Jepun di bank dan pejabat pos semasa pendudukan Jepun. Walau bagaimanapun, kerajaan British cuba memenuhi desakan yang berterusan daripada komuniti Chettiar yang menuntut keadilan ekonomi melalui perundangan.

\section{Penguatkuasaan Undang-Undang Kerajaan Malayan Union dan Persekutuan Tanah Melayu}

Seperti yang dijanjikan, pada 5 Ogos 1947, kerajaan Malayan Union mula menguatkuasakan Titles of Land (Occupation Period) Ordinance, 1947. Klausa 2 dan 3dalam ordinan ini telah menimbulkan reaksi sertamerta dalam kalangan komuniti Chettiar. ${ }^{48}$ Klausa 2 (2) menetapkan sekiranya ejen yang beroperasi semasa pendudukan Jepun masih berperanan di bawah principal yang sama selepas perang, maka ejen tersebut harus dikawal. Klausa 3 pula menetapkan sesuatu urusan transaksi tanah semasa pendudukan Jepun tidak semestinya dianggap terbatal kerana ejen yang sama telah mengendalikannya tetapi undangundang harus dirujuk. Pada tahun 1946, melalui petisyen All Malaya Nattukottai Chettiars Association, komuniti Chettiar meminta kerajaan koloni untuk mengiktiraf segala harta tanpa 'title' yang diperolehi semasa pendudukan Jepun. Justeru, pada 24 Oktober 1947 wakil kerajaan India menulis surat kepada kerajaan Malayan Union tentang bantahan komuniti Chettiar terhadap beberapa klausa dalam ordinan ini. Kerajaan India berpendapat bahawa...great hardslip would be caused 
to Chettiars whose operations in Malaya over a period of years had nate rially helped to develop the country. ${ }^{49}$

Pada tahun berikutnya, kerajaan koloni telah menguatkuasakan The Debtor-Creditor (Occupation Period) Ordinance, 1948. Komuniti Chettiar menunjukkan protes secara langsung terhadap ordinan ini kerana dijangka akan melenyapkan segala harta yang dikumpulkan sebelum perang dan semasa pendudukan Jepun. Peruntukan Seksyen 4 telah menimbulkan pelbagai reaksi dalam kalangan pemiutang dan penghutang. Seksyen 4 (2) pula menjelaskan keadaan-keadaan ${ }^{50}$ tertentu yang menyebabkan bayaran hutang sebelum perang semasa pendudukan Jepun dianggap terbatal. Seksyen 5 menjelaskan tentang hutang yang berlaku semasa pendudukan Jepun (15 Februari $1942-5$ September 1945). Sekiranya urusan peminjaman wang berlaku dari 15 Februari 1942 hingga 31 Disember 1942 serta penghutang telah menjelaskan segala bayarannya dalam tahun itu juga, maka hutang itu dianggap selesai. Namu hutang yang tertunggak selepas tahun 1942, perlu dijelaskan dalam mata wang yang diiktiraf oleh PTB atau kerajaan Malayan Union.

Seksyen 6 menyatakan bahawa sesuatu hutang akan terbatal sekiranya nilai hutang yang berlaku semasa pendudukan Jepun itu tidak melebihi $\$ 100$. Hutang juga dianggap terbatal sekiranya kreditor menolak bayaran hutang sebelum tarikh 13 Ogos 1945. Mengikut peruntukan seksyen 10 , penetapan bunga bergantung kepada sama ada hutang berlaku sebelum atau selepas pendudukan Jepun. Bunga melebihi 3 peratus dikenakan ke atas pinjaman yang dibuat sebelum perang manakala pinjaman yang dilakukan semasa pendudukan Jepun tidak akan dikenakan apa-apa bunga ${ }^{5}{ }^{5}$ Ordinan ini juga tidak memberi banyak kebebasan kepada kreditor untuk bertindak secara persendirian. Namun mereka terpaksa menerima khidmat nasihat daripada pegawai pejabat daerah atau pejabat tanah. Akibatnya, komuniti Chettiar mula memfailkan kes ke atas ejen-ejennya di mahkamah. ${ }^{52}$

Pada 29 Mac 1948, komuniti Chettiar bersama anggota MIC dan AMCJA-PUTERA telah bermuafakat untuk memboikot reformasi dalam perundangan Malayan Union serta mengkritik ordinan ini. ${ }^{53}$ Mereka berpendapat undang-undang ini diwujudkan untuk memperkukuhkan kawalan kewangan Eropah di Tanah Melayu di bawah perbelanjaan pengusaha bank yang terdiri daripada orang India dan Cina, mengutip semula kredit orang British semasa perang dan pendudukan Jepun serta menyekat modal peniaga India di Tanah Melayu.$^{54}$ Pakatan telah menyimpulkan manifestasi undang-undang ini bertujuan melengahkan polisi sehingga menamatkan kedudukan ekonomi orang India serta memperluaskan kawalan ekonomi orang Eropah di rantau Asia. 
Dalam keadaan hidup yang terdesak selepas pendudukan Jepun, komuniti Chettiar juga mula mengambil iktibar untuk mendapat naungan politik sekiranya dapat membantu mengembalikan kedudukan ekonomi mereka. Beberapa anggota komuniti Chettiar yang berpengaruh seperti O.A.R Arunasalam Chettiar di Melaka mula bergiat dalam MIC serta menggunakan pengaruhnya di Melaka, Selangor dan Negeri Sembilan untuk menyokong pelantikan Ramanathan Chettiar sebagai presiden MIC.55

\section{Penguatkuasaan Moneylenders Bill, 1951}

Dari tahun 1946 hingga 1957, Persekutuan Tanah Melayu (PTM) sedang mengalami anjakan pembangunan politik yang drastik dengan semakan semula undang-undang lama serta pengenalan undang-undang baharu oleh kerajaan koloni untuk menyediakan Persekutuan Tanah Melayu ke arah kemerdekaan dan berkerajaan sendiri. Dalam pergelutan politik ini, sekali lagi kedudukan ekonomi komuniti Chettiar tercabar akibat penguatkuasaan Moneylenders Bill, 1951. ${ }^{56}$ Pada 14 September 1952, komuniti Chettiar telah menghantar memorandum sebagai reaksi terhadap beberapa perkara dalam undang-undang ini yang secara langsung akan menamatkan kegiatan peminjaman wang mereka. ${ }^{57}$ Mengikut ordinan ini, kegiatan peminjaman wang akan dihadkan mengikut negeri kerana kerajaan yang menguatkuasakannya tidak berhasrat untuk menyeragamkan lesen peminjaman wang. Komuniti Chettiar memprotes disebabkan kerajaan PTM tidak mengendahkan tuntutan mereka untuk menetapkan bunga maksimum 12 peratus (secured loan) dan 18 peratus (unsecured loan) setahun. ${ }^{58}$

Chettiar juga membantah penetapan kerajaan yang mengarahkan komuniti Chettiar untuk meletakkan papan tanda di hadapan premis firmanya dan mewajibkan 'promissory note' ditandatangani oleh majistret atau seorang penerima anugerah 'Justice Of The Peace'. Sesungguhnya inilah buat pertama kali, pihak British menguatkuasakan undang-undang untuk mengawal kegiatan peminjam wang di Tanah Melayu. Pada tahun 1952, lebih daripada 100 wakil komuniti Chettiar daripada sel uruh Persekutuan Tanah Melayu telah menunjukkan protes dengan menghentikan aktiviti peminjaman wang selama tiga bulan. ${ }^{5 \prime}$

Komuniti Chettiar nula berputus asa dan beranggapan adalah mustahil untuk mereka beroperasi di bawah ordinan itu. Justeru, terdapat dalam kalangan komuniti Chettiar yang mengusulkan untuk memulakan bank dengan modal yang sedia ada. Komuniti Chettiar juga berpendapat penghijrahan ke India juga tidak praktikal kerana wang modal sebanyak $\$ 300,000,000$ yang dilaburkan dalam sektor perladangan getah dan perumahan masih belum dituntut. Mereka juga 
khuatir kerajaan PTM akan mengawal pengiriman wang (remittance) ke India serta membekukan harta mereka. ${ }^{60}$ Mulai tahun 1952, komuniti Chettiar yang memiliki ladang-ladang getah telah memohon Skim Penanaman Semula Getah. Dari tahun 1952 hingga 1957, banyak kes sivil melibatkan komuniti Chettiar dengan penghutang yang meminjam atas cagaran tanah difailkan di mahkamah Persekutuan Tanah Melayu. Menjelang kemerdekaan ramai dalam kalangan komuniti Chettiar telah pulang ke India dan bilangan peminjam wang dalam kalangan mereka semakin berkurangan pada tahun-tahun berikutnya. ${ }^{61}$ Sekitar tahun 1960-an dan 1970-an, banyak ladang getah milik Chettiar telahpun dijual kepada orang Cina.

\section{Kesimpulan}

Komuniti Chettiar telah memainkan peranan yang dominan dalam era dasar perdagangan bebas (Laissez-Faire) British di Tanah Melay u mulai abad ke-19 sehingga awal abad ke-20. Chettiar telah menyediakan pinjaman atau bantuan kewangan tanpa sebarang jaminan kepada pengusaha ladang, pelombong bijih timah dan pekedai runcit. Peranan berharga komuniti Chettiar terjejas apabila Jepun menduduki Tanah Melayu dan memusnahkan ladang-ladang dan lombong milik Chettiar dan mewajibkan penggunaan mata wang Jepun. Nasib komuniti Chettiar tidak terbela selepas British kembali memerintah Tanah Melayu di bawah PTB dan Malayan Union. Tindakan PTB yang mengisytiharkan "Currency Proclamation" yang bererti hanya mata wang Malaynan Notes yang sah menyebabkan mata wang Jepun menjadi tidak sah dan bernilai. Langkah ini menyebabkan Chettiar mengalami kerugian sebanyak 120 juta straits dollar dan separuh daripada kerugian ini adalah dalam industri perladangan getah dan aktiviti peminjaman wang.

Dalam era selepas pendudukan Jepun, British memperkenalkan pelbagai perundangan dan menubuhkan Lembaga Kemusnahan Perang bagi memulihkan ekonomi Tanah Melayu tetapi kesemuanya tidak berupaya untuk membela kedudukan ekonomi komuniti Chettiar. Malahan undang-undang ini telah menyukarkan lagi kehidupan komuniti Chettiar. Kemuncak rasa tidak puas hati komunti Chettiar telah dimanifestasikan melalui penubuhan All Malaya Nattukottai Chettiar Association pada 1946 bagi menghantar petisyen kepada Pejabat Tanah Jajahan di London untuk meneliti kedudukan ekonomi mereka di Tanah Melayu. Penubuhan Malayan Indian Congress (MIC) di bawah pimpinan seorang Chettiar pada 1946 juga merupakan satu usaha nekad bagi memperjuangkan kepentingan komuniti Chettiar melalui saluran politik. 
Secara umum komuniti Chettiar yang telah memainkan peranan dalam perkembangan ekonomi Tanah Melayu sebelum pendudukan Jepun tidak terbela selepas British kembali memerintah antara 19451957. Pelbagai ordinan dan Lembaga yang ditubuhkan dalam waktu ini tidak dapat mengembalikan sumber kewangan Chettiar yang hilang nilai pada era pendudukan Jepun.

\section{Nota}

Mengikut Kamus Dewan, ceti bermaksud pelepas wang atau peminjam wang. Perkataan ceti juga merupakan kata nama am yang merujuk kepada golongan pedagang berketurunan India di India Selatan. Mengikut leksikon bahasa Tamil, Cettu ialah kata dasar untuk perkataan ceti. Cettu membawa dua makna iaitu pertama, chikkanam y ang bererti jimat-cermat dan keduanya, adalah keuntungan daripada perdagangan. Perkataan ceti juga dipercayai berasal daripada perkataan 'Etti' yang bermaksud gelaran yang dikurniakan kepada pedagang yang berjaya dalam kerajaan Tamil Chola dan Pandya,. Perkataan 'Etti' dikonotasikan menjadi 'ceti'. Perkataan ceti dipercayai berasal daripada perkataan 'shresti' dalam bahasa Sanskrit. Shresti membawo maksud superior atau leader of a merchant guild.S. Chandrasekhar, 'The Nagarathars - The Land, The People And 'Their Marriage (and population) Registration System,' Population Review, January-December, 1976, hlm. 26.

2 Perkataan Chettiar menjadi popular pada awal abad ke-20 dan pada tahun 1930. Persatuan Nattukottai Chettiar Klang mendesak kerajaan British menggantikan gelaran ceti kepada chettiar sebagai panggilan honorifik. SSF 2743/1924, Dokumen: Permintaan Jawatankuasa Seminar Komuniti Chettiar SeMalaya, 19-20 Mei 1924; SSF 2549/1930, Dokumen: Resolusi yang diluluskan di mesyuarat tahunan Persatuan Nattukottai Chettiar, F.M.S di Klang pada 5 Disember 1930. Chettiar juga merujuk kepada golongan ceti yang berketurunan Tamil dan beragama Hindu di India Selatan. Terdapat juga ceti berbeketurunan Telugu, Malayalam dan Sikh. Perkataan Chettiar akan digunakan sepanjang penulisan ini.

3 Menurut sastera Sangam, 'Pattinattupaalai', hubungan perdagangan antara komuniti ceti di Kaveripoomipatinum (pelabuhan di pantai Choramandel) dengan Kadaram [Kedah] wujud sejak abad ke-7 Masihi lagi. Muthupalaniappa Chettiar, Happy Malaya, Pulau Pinang, 1938, hlm. 9-10. Pensejarahan komuniti ceti tidak jelas dari abad pertama tahun masihi hingga abad ke-15 kerana kebanyakan rekod tidak mempunyai catatan khusus tentang komuniti ceti tetapi dirujuk sebagai pedagang India. Beberapa sumber Tamil yang mengisahkan sejarah komuniti ceti menegaskan pedagang India merujuk kepada komuniti ceti. Rekod Portugis tentang kerajaan Melaka telah merakamkan serba sedikit tentang kegiatan ekonomi komuniti ceti dan ketokohan Nina Chatu sebagai ketua pedagang India dari tahun 1508 hingga 1514. Untuk keterangan lebih lanjut tentang Nina Chatu dan komuniti ceti pada era Portugis di Melaka rujuk Thomaz, Luis Filipe F. Reis (translated by M.J Pintado), Nina Chatu 
and the Portuguese Trade in Malacca, Bandar Melaka: Luso-Malaysian Book, 1991; Armando Cortesao, (ed.and tsd.), The Suma Oriental of Tome Pires, Vol. I \& II, London: Hakluyt Society, 1944 dan M.J Pintado (collected, translated and annotated) Portuguese Documents On Malacca, Vol. I, 15091511, Malaysia: Arkib Negara Malaysia, 1993. Setakat ini, dalam kalangan sejarawan tempatan, $\mathrm{S}$. Arasaratnam yang telah banyak menghasilkan penulisan tentang kegiatan pedagang India pada era Belanda di rantau Asia Tenggara termasuk Selat Melaka. Walaupun Arasaratnam banyak menggunakan istilah pedagang India tetapi beliau tidak menafikan peranan komuniti ceti di pantai Koromandel (Choramandel). Untuk rujukan lebih lanjut tentang kegiatan pedagang India di rantau Asia Tenggara. Rujuk Arasaratnam Sinnappah, "Aspects of the Role and Activities of South Indian Merchants c. 1650-1750,' Proceedings of The First International Conference Seminar of Tamil Studies, Kuala Lumpur Malaysia, Vol. 1, April 1966; 'Some Notes On The Dutch In Malacca And The Indo-Malayan Trade 1641-1670,' Journal Of Southeast Asian History, Vol.X, No.3, Disember 1969.

4 Dasar British di Tanah Melayu sehingga awal abad ke-20 boleh diistilahkan sebagai laissez-faire. Suatu dasar di mana British tidak campurtangan dalam hal-ehwal ekonomi kaum imigran dalam sektor perlombongan dan perladangan. Kelonggaran ini dapat dilihat dalam undang-undang imigrasi yang longgar untuk menggalakkan kemasukan kaum imigran Cina dan India; pembukaan tanah secara liberal, membenarkan penubuhan kongsi gelap untuk mengawal kegiatan buruh Cina dan pengenalan sistem pajakan hasil. Dasar liberal ini telah membantu British mengur us ekonomi negeri-negeri Melayu tanpa pembiayaan sendiri. Untuk keterangan lebih lanjut tentang dasar laisse-faire rujuk Sadka, Protected Malay States, 1874-1895, Kuala Lumpur: University of Malaya Press, 1968, hlm. 336 dan Sivachandralingam Sundara Raja, Sejarah Perdagangan Bebas, Kuala Lumpur: Penerbit Universiti Malaya, 2005, hlm. 56 \& 116 (rujuk nota kaki nombor 40).

5 Compton Mackenzie, Realms Of Silver: One Hundred Years Of Banking In The East, London: Routledge \& K. Paul, 1954, hlm.108.

- Muthupalaniappa Chettiar, Happy Malaya, Pulau Pinang, 1938, hlm.154. (Penulis mencatatkan Melaka merupakan negeri pertama ditanam dengan pokok getah di Tanah Melayu).

7 Menurut Drabble, Tan Cheng Lock telah meminjam sebanyak $\$ 10$ juta daripada Chettiar pada tahun 1921. John H Drabble, An Economic History Of Malaysian, C. 1800-1990, London: Macmillan Press Ltd., hlm. 54.

$8 \quad$ Kebanyakan ladang getah komuniti Chettiar adalah kurang daripada 100 ekar (swallholdings) dan tertumpu di Negeri Sembilan, Selangor, Perak dan Johor.

\% Sunday Times, 7 Julai 1934.

10. Directory Of Malaya tahun 1929 mencatatkan jumlah kawasan lombong y ang dipajakkan oleh Chettiar kepada kongsi Cina di Perak dan Selangor. Pada tahun 1929, Ramanathan Chettiar memajak 20 ekar kawasan perlombongan di Pusing, Perak kepada kongsi Choong Hing (hIm. 20); 
M.S.Ramasamy Chetty memajak 56 ekar tanah lombong di Gopeng kepada kongsi Heng Phoe (hlm. 23) dan 43 ekar lagi di daerah Gopeng kepada kongsi Lay Seng Hoe (hlm. 35), sementara Sathappa Chetty pula memajak 29 ekar di Siputeh kepada kongsi Weng Pow Khee, Directory of Malaya, 1929.

11 Menurut akhbar The Indian, pada 5 Julai 1937, cawangan The Indian Overseas Bank dibuka di Pulau Pinang. The Indian, 3 Julai 1937, hlm. 6. The Indian Overseas Bank juga mempunyai cawangan di Melaka, lpoh dan Kuala Lumpur. 1991/0012136, Laporan Pengarah dan Kunci Kira-kira, The Indian Ooerseas Bank Ltd., Madras, 31 Disember 1945, hlm. 1. Pengasas Chettinad Bank Ltd. di Tanah Melayu ialah S.R.M.M.A Annamalay Chettiar yang telah membuka cawangan bank di Kuala Lumpur pada tahun 1930 dan telah melaburkan segala harta tidak bergerak di negeri Selangor sebagai deposit bank. SSF 1238/1930, Surat Kok Chin Yin (peguam) kepada Residen British Selangor, 17 Jun 1930.

12 Untuk keterangan lanjut tentang sejarah pendudukan Jepun rujuk Paul 1 Kratoska, The Japanese Occupation Of Malaya, 1941-45: A Social and Economio History, London: Hurst \& Co., 1998.

13 Menurut Paul H. Kratoska, "The military administration spent the first months after the British survender attempting to repair war damage and overcone local shortages. Once these matters were under control, if began introducing a series of regulations which mooed the contry toward centralized economic planing, shifting Malaya" from liberal to a planned econony" in order to promote economic reconstruction and increase fighting pozer." Domei ELB,9 September 1943, BMA PS/ 410 Pt.1 dalam lbid., hlm. 155.

14 Sebelum Perang Dunia Kedua, nilai matawang Jepun adalah separuh daripada 'straits dollar' tetapi selepas enam bulan pendudukan Jepun, edaran matawang Jepun turun sebanyak 50 peratus. Duit syiling pula dimansuhkan. Simpanan deposit di pejabat-pejabat pos mula berkurangan dan akhirnya lenyap. Untuk gambaran keseluruhan tentang kedudukan matawang Jepun semasa dan selepas pendudukan Jepun, sila rujuk, Pau ] H.Kratoska, 'Banana Money: Consequences Of The Demonetization Of Wartime Japanese Currency In British Malaya,' Journal Of Southeast Asian Studies, Vol. 23, No.1, Mac 1992, hlm. 322-345.

15 Ejen selalunya dibekalkan dengan wang pendahuluan sebelum bertolak ke Tanah Melayu. Di bawah perbelanjaan firma, tukang masak, dobi dan tukang kira-kira (akauntan) akan turut serta. Ejen diarahkan untuk menyimpan segala rekod perbelanjaan dan saraan hidup ketika berada di Tanah Melayu. Principal (rujuk, nota kaki no. 14) akan membayar gaji ejen setelah menolak segala perbelanjaannya di Tanah Melayu. Adakalanya ejen terdiri daripada orang tempatan Tanah Melayu yang terdiri daripada orang Cina dan India.

1s Perkataan ini merujuk kepada pemilik perniagaan (proprietor), firmafirma peminjaman wang serta pembekal kredit dalam kalangan komuniti Chettiar. Mereka melantik ejen-ejen dalam kalangan komuniti Chettiar yang terdiri daripada adik-beradik, sanak-sau dara dan orang sekampung untuk mengurus perniagaan mereka di Tanah Melayu. Perkataan ini 
digunakan semasa mengemukakan petisyen dan memorandum melalui All Malaya Nattukottai Chettiar Association.

$17 \mathrm{CO} 273 / 672 / 50007 / 208$ (9), The Humble Petition Of The All-Malaya Nattukottai Chettiars' Association, hlm. 3. Komuniti Chettiar juga dilantik sebagai pengerusi cawangan International Indian League (IIL) di beberapa estet di Tanah Melayu untuk menaungi aktiviti mereka. Ravindra K. Jain, South Indians On The Plantation Frontier In Malaya, Kuala Lumpur: University of Malaya Press, 1970, hlm. 303. Akhbar Jananayagam telah menyiarkan pendapat pembaca bernama Sundram (kerani di estet) dari Banting seperti berikut,"Kami dibawa oleh ejen Chettiar ke Tanah Melayu untuk bekerja di estet tetapi semasa pendudukan Jepun, ejen Chettiar mengambilalih peranan principal dan memberi tekanan kepada kerani," Jananayagam, 13 Mac 1946, hlm. 4.

18 HQ B.M.A Malacca 504/45, Surat Chettiar Chambers, Malacca kepada S.K. Chettur, I.C.S., Indian Agent General, Malaya, Kuala Lumpur.

19 Ibid.

20 Ibid

21 Paul H. Kratoska, The Japanese Occupation Of Malaya: A Social And Economic History, hlm. 215. Menurut laporan bank, "Di Pulau Pinang, tentera Jepun telah menutup bank-bank milik British seperti Chartered Bank, Hongkong \& Shanghai Bank dan Mercantile Bank Of India Ltd. Selain membenarkan pengoperasian The Indian Overseas Bank Ltd. dan Indian Bank Ltd., pihak Jepun juga telah membuka bank mereka iaitu Nanpo Kaihatsu Kinko dan Yokohama Specie Bank". D.C.C.A.O 184/1945, Dokumen CASM (FIN) 012, hlm. 2 (fail Banking (Penang) - General).

22 Syuseityo Kanbo 52/2602 (1942), Surat Chettinad Bank Ltd. kepada Gabenor Selangor (syuseityo Kanbo), 11 Jun 1942; Surat Gabenor kepada peguam yang dilantik oleh Chettinad Bank Lttd., 29 Jun 1942. (Application From Chettinad Bank Limited For A Licence Under The Companies Enactment (chapter 58) To Conduct Banking Business.) $x$

23 D.C.C.A.O 184/1945, Dokumen CASM (FIN) 012, hlm. 2.

24 Pada 30 September 1943, tentera Jepun mengambil tanah-tanah (Nombor Lot : 4232, 4292 dan 4296) Alagappa Chettiar setelah dibayar pampasan sebanyak 5,640.00 dalam mata wang Jepun ( $1,673.60$ dalam "Malayan Currency") pada 29 November 1943. SSF 2982/1949, Butiran tentang geran tanah daripada Pegawai Daerah Klang kepada Setiausaha Negeri, Selangor, Februari 1950 (tiada tarikh). Tanah-tanah Ramanathan Chettiar di Jalan Port Swettenham-Jalan Watson diambil oleh tentera Jepun pada 30 September 1943 setelah membayar pampasan sebanyak $\$ 16,490$ (\$ 4, 893.20 dalam "Malayan Currency") pada 29 November 1943. SSF 2984/1949, Butiran tentang geran tanah daripada Pegawai Daerah Klang kepada kepada Setiausaha Negeri, Selangor, 25 Mac 1950.

25 British Military Administration Malaya, Proclamation - Moratorium Proclamation ["A Proclamation to close financial institutions, to proclaim a Moratorium and to prohibit certain dealings in Land"]. Moratorium diumumkan pada 30 Ogos 1945 dan dijangka tamat pada September 1946. 
2. Terdapat dua kategori tanah di Tanah Melayu. Kategori S.G adalah tanah-tanah di bandar, perlombongan dan pertanian yang melebihi 10 ekar, tertakluk kepada 'Central State Registries Of Title' dan mempunyai nilai modal yang tinggi. Manakala, kategori E.M.R adalah tanah-tanah negeri di bawah 10 ekar, pendaftaran di bawah pejabat tanah daerah dan mempunyai nilai modal yang rendah. Selepas pendud ukan Jepun, pengurusan tanah menjadi masalah besar kepada pentadbir British di Tanah Melayu. D.C.I 61/1946, Dokumen-Problem Of Moratorium.

27 Chief Civil Affairs Officer mempunyai kuasa penuh untuk memutuskan segala hal berkaitan matawang. Menurut The Currency Proclamation, "(i). Currency notes inscribed "Government of the Straits Settlements" issued by the Board of Commissioners of Currency estalished under the Straits Settlements Currency Ordinance (Cap.219), excepting notes of the denoninations of one thousand dollars and ten thousand dollars and ofless than one dollar; (ii). Malayan currency notes issted by the Board of Commissioners of Currency, Malaya, except notes of denominations of less than one dollar... No other currency or coin shall be legal tender." British Military Administration Malaya, Proclamation: A Proclamation To Define Lega] Tender And To Regulate Currency Signed At Sea This 30 ${ }^{\text {th }}$ Day Of August 1945; M.DIVISION GENERAL Gen/142, Dokumen, Currency Proclamation Amendments.

$28 \mathrm{CO} 273 / 672 / 50007 / 208$ (18), Opinion of Tej Bahadur Sapru, In The Mafter Of Their Transactions In Malaya And Burma, hlm. 123. (Tej Bahadur merupakan peguam terkenal dari Allahabad dan amat arif dalam arena perundangan antarabangsa. Komuniti Chettiar di Madras (Principal) telah mendapatkan khidmat nasihat perundangan beliau semasa mengemukakan memorandom kepada Setiausaha Kerajaan Koloni di London).

29. British Military Administration Malaya Monthly Report No.6, February 1946, hlm. 27. Sebelum tahun 1946, kebanyakan Dewan Perniagaan Komuniti Chettiar (Chettiars Chamber Of Conmerce) adalah di peringkat daerah dan negeri.

30 Roland St. John Braddell dilahirkan di London pada 20 Disember 1880 Pada tahun 1906, beliau mula bekerja untuk firma milik ayahnya, Logan \& Braddell di "Bar Of Straits Settlements", Singapura. Beliau mempunyai 50 tahun pengalaman bekerja sebagai pegawai undang-undang di Tanah Melayu dan Singapura. Beliau juga pernah dilantik menjadi penasihat undang-undang Sultan Johor sebelum Perang Dunia Kedua dan UMNO pada tahun 1946. Beliau juga memainkan peranan penting dalam rundingan Perlembagaan antara tahun 1948 hingga 1951. Datok Sir Roland Braddell, The Study Of Ancient Tines In The Malmy Peninsula Es Straits Of Malacca, M.B.R.A.S, Reprint No.7, 1980, hlm. vii.

3 Dr Sir Tej Bahadur Sapru (Allahabad), Sir Alladi Krishnaswamy lyer (Madras), M.C Satalvad (Ex-Advocate General, Bombay) dan Daphtary (Advocate-General, Bombay).

32 CO 717/164, K. Ramanathan, Surat Setiausaha, All Malaya Nattukottai Chettiars Association kepada Setiausaha Koloni di London, 5 Feb. dan 18 Mac 1947. 
3.) Ibid.

$34 \mathrm{CO} 273 / 672 / 50007 / 208$ (9), The Humble Petition Of The All-Malaya Nattukottai Chettiars' Association, hlm. 4.

35 Menurut petisyen All Malaya Nattukottai Chettiars Association, "Loss or damage faced by the people of Malaya relatively small compare to other contries occupied by the enemies but Colony was riolently changed under conditions more or less of duress by the introduction of a military currency by the Japanese Military Administration and the subsequent repudiation of that currency by the British Military Administration. Any measure which the Governmuet may decide to lake to distribute the real loss arising out of the war reasonably fairly over the entire population of Malayn, will be whole - heartedly welcomed by the Chettiars," Ibid.

36 Badan ini juga mempengaruhi kerajaan dalam membuat keputusan dalam proses penyiasatan sesuatu tuntutan yang dibuat, mekanisme bayaran, dan golongan yang harus diutamakan dalam tuntutan. Pampasan harus dituntut ke atas kemusnahan atau kerugian yang disebabkan oleh pengeboman atau letupan, atas arahan kerajaan atau tentera Jepun atau rampasan oleh tentera Jepun. Tuntutan hanya boleh dibuat ke atas tanah, bangunan, mesin, pokok-pokok getah, pokok-pokok yang sedang tumbuh, barangan, pakaian, dan perabot. Perkara-perkara yang tidak boleh dituntut adalah wang serta dokumen yang hilang, kehilangan nyawa, terjejasnya kesihatan, kecederaan dan kehilangan pendapatan. R.C. SELANGOR 384/1946, Terms of Reference of the Malayan War Damage Claims (Dokumen 40B) hlm. 1-2.

37 D.O.T No 58/1947, Circular (No.32 in W.D.C. 1/46) daripada Setiausaha War Damage Claims Commission (Butiran ini terdapat dalam Dokumen 4;WDL.6), 8 November 1946.

38 Dalam perbahasan bertarikh 31 Mac 1954, dinyatakan kerajaan Jepun telah meny umbang sebanyak $\$ 34$ juta dalam tabung kemusnahan perang sebagai gantirugi kepada harta penduduk Tanah Melayu; Jumlah harta tentera Jepun di Tanah Melayu di bawah pemeliharaan harta musuh kerajaan Persekutuan Tanah Melayu dijangka berjumlah $\$ 44$ juta. Proceedings Of The Federal Legislative Council (7th Session) - March 1954 to January 1955, hlm. 867. Perkara-perkara yang boleh dituntut adalah seperti yang ditetapkan oleh War Damage Commission. Kerajaan Jepun harus membayar pampasan ke atas 'war effort' seperti kos tahanan serta kematian penduduk Tanah Melayu, kos perkhidmatan yang digunakan semasa pendudukan (contoh: perkhidmatan kereta api), dan di bawah kategori penyelenggaraan adalah eksploitasi sumber bumi di Tanah Melayu. Kerajaan Malayan Union juga menetapkan segala borang tuntutan harus dikemukakan pada 31 Mei 1947, hlm. 1-2. L.O.B 44/1946, Surat Setiausaha Kerajaan Malayan Union kepada Ketua-ketua Jabatan Kerajaan, 12 April 1946, hlm.1. Pada 30 April 1946, Jabatan Perlombongan Tanah Melayu mengemukakan gantirugi sebanyak $\$ 374,600,000$ (atau 43,700,000 'straits dollar') kepada jawatankuasa. L \& C No. 17/N, Surat Chief Inspector of Mines kepada Ketua Setiausaha, Malayan Union, 30 April 1946 (Dokumen 21 A), hIm. 1. 
39. Pada tahun 1948, Encik Carson, Pengerusi lembaga Kemusnahan Perang menyediakan cadangan memorandum untuk skim ini berdasarkan tuntutan yang diterima daripada lembaga. Akibat kekurangan kakitangan dan taburan fail-fail pejabat daerah dan tanah di selu ruh Tanah Melayu telah menyebabkan skim ini hanya dapat dimulakan pada tahun 1949. War Damage Commisson, Federation Of Malaya And Singapore - Report In Which Is Included The Annual Report For 1952, hlm.12. Pada 2 September 1948. Memorandum untuk cadangan pelancaran Skim Kemusnahan Perang dibentangkan dalam Majlis Perundangan Persekutuan. Mengikut cadangan, bayaran pampasan di bawah skim ini digabungkan dengan War Risks (Goods) Insurance Scheme, satu-satunya skim pampasan yang beroperasi semasa pendudukan Jepun tetapi terhad kepada tuntutan ke atas barangan jualan (hlm. c326); Restoration Award hanya dibayar kepada tuntutan ke atas kerugian yang dialami dalam industri dan perniagaan manakala Outright Award pula dibayar kepada "chattels" dalam perniagaan (hlm. c 338). Mengikut pernyataan Pampasan Kemusnahan Perang yang diumumkan pada 27 April 1948, Skim Kemusnahan Perang dijangka akan menampung perbelanjaan pampasan sebanyak \$ 475,000,000 (hIm. c115). Proceedings Of The Federal Legislatioe Council (First Session) - Februany 1948 - February 1949.

4) Arkib Negara Malaysia mempunyai fail senarai penerimaan 'War Damage Commission Files' mengikut negeri. Daripada pemerhatian pengkaji, bilangan komuniti Chettiar di negeri Pulau Pinang, Melaka dan Johor agak tinggi dalam membuat tuntutan berbanding di negeri-negeri lain. Untuk rujukan lanjut tentang kemusnahan dalam industri perladangan, rujuk, Laporan, Assessment Of War Damage Claims From The Rural Planting Industry-October, 1950.

4 War Damage Commission, Penang: PG/BM/1490, tuntutan ganti rugi N.M.RM Ramanathan Chettiar dari Kampong Crost Street, Bukit Mertajam kepada War Damage Commission, 30 Mei 1947. Dalam kes pemilik estet Nagappa di Jementah (Segamat, Johor), bayaran wang tuntutan sebanyak $\$ 73,000.00$ ditunda atas sebab kerajaan Britain kekurangan wang dalam tabung Perang Kemusnahan. War Damage Commission, Iohore J/ ST/1724, Tuntutan ganti rugi R.M.MS. Karuppan Chettiar bagi pihak P.K.N. \& Co., Ltd, beralamat di 44, Jalan Awang, Segamat kepada War Damage Commission, 13 Mac 1954.

4: War Damage Commission Penang; PG/SW/441, Laporan penyiasatan War Damage Commission.

4. War Damage Commission Penang; PG/SW/449, Tuntutan ganti rugi oleh T.PL.VE.KR. Kathiresen Chettiar dari Balik Pulau kepada War Dantage Commission, 14 Mei 1947; Laporan penyiasatan War Damage Commission pada tahun 1951.

44 War Damage Commission Perak: PK/7/3822, Meyappa Chettiar kepada The Rubber Adriser, War Damage Conmision, 18 Nov. 1950.

45. War Damage Commission Penang: PG/B/1267, Timbalan Pengerusi, War Damage Commission kepada Collector of Estate Duty, 26 Mac 1956. Beberapa kes melibatkan tuntutan oleh ejen Chettiar boleh diperolehi daripuda 
fail-fail berikut: War Damage Commission Penang: PG/B/614 - N.AL.KR Karuppan Chettiar, 2981, Bagan Luar Road, Butterworth; P.W.N; PG/ BM/527 - AR.PL.Letchumanan Chettiar, Penang Street, Penang; War Damage Commission Pahang: PHG/TEM/1269 - Palaniappa Chettiar, 4, Jalan Maharani, Muar.

46 SUK Kedah T.H 1357 - T.M 1938, Jilid II. - S.C 2287/1357, Dokumen: Requests That State Treasurer Be Asked To Deduct \$70/- Monthly From Her Ruling House Allowance For Payment To S.A.R.M Maiyappa Chettiar.

47 Berikut adalah jawapan bertulis untuk soalan yang dikemukakan oleh J.D Mead tentang jumlah wang premium yang terkumpul di bawah tabung War Risks (Good) Insurance untuk membayar pampasan: Pada tahun 1948 jumlah tuntutan penduduk Persekutuan Tanah Melayu dan Singapura ialah $\$ 196$ juta manakala wang tabung insuran pada 31 Disember 1947 ialah \$11, 988, 313.07. Federation Of Malaya, Report Of The Proceedings Of The Legislative Conncil, Kuala Lumpur, Monday, 31 ${ }^{\text {si }}$ May, 1948, hlm. 20. Pada 27 Januari 1948, dalam Advisory Council, Kuala Lumpur, Encik A.W Wallich telah mengemukakan jawapan dan pandangan tentang War Risks (Good) Insurance dan Pampasan Kemusnahan Perang. Mengikut beliau, kerajaan Malayan Union juga menghadapi masalah kekurangan kakitangan untuk memproses borang-borang tuntutan yang mula membanjiri ibu pejabat lembaga di Kuala Lumpur selepas pelancaran tabung. Pada tahun 1948, beberapa cadangan dibahaskan dalam Majlis Perundangan Persekutuan. Antaranya adalah mengasaskan ibu pejabat induk di Kuala Lumpur, peningkatan kakitangan, panduan prosedur tuntutan yang jelas dan fleksibel serta maklumat peruntukan tabung seperti sumber dan tempoh masa tuntutan yang mudah difahami. Pada tahun 1948, pegawai -pegawai yang menguruskan tuntutan terdiri daripada 20 orang Eropah dan 51 orang Asia. Proceedings Of The Malayan Union Advisory Council And Federal Legislatize Council, part. 1, January-July 1948, hIm. 29-30.

$48 \mathrm{CO} 717 / 164$, Pesuruhjaya India kepada Under Secretary of State for Commonzealth Relations, 13 Okt. 1947.

49 Ibid.

50 (1)Pemiutang dipaksa atau diugut atau dicederakan untuk menerima bayaran, (2). Bayaran dibuat selepas 31 Disember 1943 dalam matawang Jepun, iaitu sebelum perang adalah melebihi $\$ 250$, sama ada bayaran tidak dibuat atau tidak dituntut oleh pemiutang. (3). Bayaran dibuat oleh pegawai Jepun ke atas hutang sebelum perang yang melebihi $\$ 250$. Dalam ketiga-tiga situasi ini, penghutang "is not credited with the face value of the money he repaid, but only with part of it.." Seksyen 4 (3) pula mengarahkan peminjam yang tergolong dalam mana-mana satu kategori tersebut, perlu berbincang dengan pegawai daerah atau penolongnya. Peraturan-peraturan ini tidak diguna pakai untuk bayaran sewa tanah. SEL. CIVIL AFFAIRS 40/1945, Dokumen: Moratorium Proclamation - 11; Transactions In Land: General Policy regarding land acquired by Japanese. Seksyen 4 juga telah dibahaskan secara panjang lebar semasa perbahasan 
bertarikh 16 Disember 1948. Procedings Of The Federal Legislative Conncil, Part II, July-December 1948 (Report), hlm.19-38.

51 Menurut The Indian Daily Mail, Komuniti Chettiar juga sanggup menerima kadar bunga yang lebih rendah tetapi pemiutang tidak mahu meleretkan perkara ini ke mahkamah. Mereka juga berpendapat perkataan ejen yang dibincangkan dalam ordinan ini lebih sesuai untuk ejen bank. The Indian Daily Mail, 6 April 1948, hlm. 4.

52 Untuk keterangan tentang ejen-ejen yang terdiri daripada kalangan Chettiar, orang India dan Cina, di Tanah Melayu yang menghadapi tindakan mahkamah, rujuk, kes Suppiah Chettiar v. Ong Pee Koi And Another (hIm. 49-55), A.L.SSadayappa Chettiar v. Letchumanan Chettiar (hlm.105-107), The Firm Of A.M.K.M.K v. M.RM. Periyanan Chettiar; kes ini agak luar biasa iaitu principal i. principal; hutang sebelum perang yang dibayar habis semasa pendudukan Jepun dianggap sah kerana dari bulan Februari hingga September 1942 nilai matawang Jepun dan 'straits dollar' adalah sama. Maka, penghakiman berpihak kepada Periayannan Chettiar ( hlm. 183), Malayan Law Joumal, Vol.17, 1951.

53. Indian Daily Mail, 9 April 1948, hlm. 4.

54 Menurut Tamil Nesan, Semasa berucap dalam mesyuarat kongres di New Delhi, Chandra Bose telah membidas sikap berat sebelah British terhadap komuniti Chettiar sehingga British di Tanah Melayu tidak membantu kepulangan komu niti Chettiar ke India semasa pendudukan Jepun tetapi telah menghantar pulang warga Britain ke tanahairnya. Tamil Nesan, 18 April 1946, hlm. 4.

55 Rajeswary Ampalavanar, The Indian Minority and Political Change In Malaya, 1945-57, Kuala Lumpur: Oxford University Press, 1981, hlm. 155, 164, 169170. Menurut akhbar Jananayagam, Ramanathan Chettiar telah mengangkat sumpah sebagai presiden MIC pada 29 April, 1950. Jananalyagam, 24 April 1950, hlm.1.

50 Sebelum Pendudukan Jepun, kerajaan British menguatkuasakan Moneylending Bill, 1934 di Negeri-negeri Selat sahaja. Sebahagian besar daripada perkara dalam perundangan ini adalah tentang perlesenan dan kerajaan koloni tidak menguatkuasakan sepenuhnya. Untuk keterangan lanjut tentang Moneylending Bill, 1934, rujuk, Procedings Of The Legislative Council Of The Straits Settlements, Vol. II, 1934. Maka kerajaan koloni tidak mempraktiskan sebarang perundangan yang seragam berkaitan peminjaman wang untuk kesemua negeri di Tanah Melayu sehingga Moratorium diperkenalkan pada tahun 1946 dan Moneylenders Bill, 1951. Undang-undang ini (Moneyleuders Bill, 1951) mempunyai dua bahagian, iaitu bahagian pertama ialah perlesenan dan bahagian kedua pula tentangurusan peminjaman yang banyak telah menimbulkan kemarahan komuniti Chettiar. Perlu diambil perhatian, undang-undang ini merujuk kepada peminjam wang (moneylender) profesional (menjalankan kegiatan peminjaman wang sebagai perniagaan) dan bukannya kegiatan peminjaman wang. Pada 31 Mac 1952, Bill ini telah diluluskan sebagai ordinan. 
57 Menorandum Of The All Malaya Nattukottui Chettiars' Chamber OfCommerce, Kuala Lumpur.

58 Komuniti Chettiar telah membidas sikap British yang mengatakan peratus faedah yang dituntut oleh mereka sebagai tinggi, sedangkan sebelum perang, Singapore Bill menetapkan peratus faedah sebanyak 36 peratus hingga 48 peratus dan 96 peratus faedah dibenarkan dalam undangundang Inggeris. Ibid., hlm. 5.

59 Malay Mail, 1. Julai 1952, hlm. 2.

6) Standard, 14 Disember 1956.

61 Pengenalan Moratorium telah melenyapkan 50 peratus daripada firma peminjaman kewangan komuniti Chettiar dan selepas pengenalan Moneylenders Bill, 1951, dijangkakan ramai akan melepaskan kegiatan ini. Antara tahun 1955 hingg 1960, bilangan peminjam wang dalam kalangan Chettiar ialah 532 orang, Malay Mail, 5 Oktober 1970; Menurut laporan All Malaya Nattukkottai Chettiars Chamber Of Conmerce, 1971, pada tahun 1961 bilangan peminjam wang dalam kalangan komuniti Chettiar ialah 508 orang, Straits Times, 7 November 1975 dan angka ini menurun kepada 407 orang pada tahun 1974, Straits Times, 6 Februari 1969. 